\title{
The Contributions of Physical Education and Game Activities on Behaviors of Autistic Individuals
}

\author{
Y. Eskicioğlu ${ }^{1}$, H. Çoknaz ${ }^{1}$, A. Çelen ${ }^{1} \&$ D. Çoknaz ${ }^{1}$ \\ ${ }^{1}$ School of Physical Education and Sports, Abant Izzet Baysal University, Bolu, Turkey \\ Correspondence: H. Çoknaz, School of Physical Education and Sports, Abant Izzet Baysal University, Bolu, \\ Turkey.
}

Received: December 1, 2016

Accepted: December 23, 2016 Online Published: December 29, 2016

doi:10.20849/aes.v2i1.104

URL: http://dx.doi.org/10.20849/aes.v2i1.104

\begin{abstract}
People are expected to carry out certain roles and duties throughout their lives in a society. The inability of people to carry out their roles and duties in a society due to various factors is defined as "disability." Considering that there are 1,559,222 disabled individuals in our country, the rate holds an important place within the general population. Each individual is either disabled, has a disabled relative or a candidate for disability. Thus it is necessary to provide suitable conditions to enable disabled individuals live in concert with the society. This study is conducted in order to determine the level of influence of a 28-hour sport and game activity each week, for 14 weeks, on autistic individuals who have weak socializing and communications skills. This research is conducted on 2 male autistic children of a volunteer family during the fall semester of 2014-2015 academic year; this research also includes preliminary test and proof positive through face to face interview with the family. Descriptive analysis and content analysis are used in data analysis. All of the procedures are carried out by qualitative analysis program NVIVO 10. The names of disabled individuals who attended the research are undisclosed. In the end of this research, the statements released during the interviews show that physical education and game activities have an important influence on the development of disabled individuals. In this respect, the statements given at the end of the research are presented as Emotions and Thoughts of the Mother and Emotions and Behaviors of the Children.
\end{abstract}

Keywords: disabled, autism, play

\section{Introduction}

One of the obvious realities of nature, without a doubt, is individual differences among people. Tools, appliances and institutions created in order to respond to the needs of individuals experiencing all of these differences are handled within the scope of "special education." Accordingly, individuals are categorized depending on their differences. The result of all of these elaborations is always the same. It can be "privileged," "disabled" or "handicapped" but whatever name is given it is certain that each individual has this privilege, disability or handicap for certain activities, certain times and certain places (Illhan, 2009).

There are certain roles and duties that are expected from people throughout their lives in a society. The inability of people to carry out their roles and duties in a society due to various factors is defined as "disability" (Özsoy, et al. 2002).

Playing games is an entertaining activity, which takes shape naturally and enables the child to learn, develop creativity, discharge his/her energy and initiate social interaction. Game activity changes according to the age group. In order to define an activity as game, it is required that the child initiates it, wants it, accepts its rules and more importantly the child has fun (Odluyurt, 2013).

Fewel (1997) considered game as a developmental concept and structured it on the sequential nature of skill gaining, because game skills are essential for social adaptation. It is associated with language development, social skills and general cognitive functions. Game skills are important in understanding and attending the game for children who require special education as well as children with normal developmental process. Children with developmental delay can be limited within their own game skills and frequently lack similar peculiarities that their peers with typical development have and thus may not be able to experience similar benefits from the game. 
However, it should be remembered that children with developmental delay like playing games the same way the children with normal developmental process (Fewel, 1997 qtd in Ayan, 2012).

Playing games is not only an activity which is present in all phases of our lives, but also is the most proper expression type which enables the child to learn the world that he/she lives in and to express his/her emotions such as happiness, anxiety and joy during the first years. Children learn to discover and imitate the models they see in life and develop their already existent skills by playing games. Howes and Rubin (1983) argue that due to their limitations in cognitive and perceptive fields, autistic children have limited skills in understanding, building relationships, solving problems and communicating. One other peculiarity of autistic children is their inadequacy in social development. Kanner argued in 1943 that social inadequacy was the most important symptom of autism. There are certain peculiarities of autistic children: they abstain from physical contact, they do not form eye contact especially during the first years, when others smile at them they do not smile back, they are indifferent to other people, they are limited to understand social rules and have limited playing skills. Limited game skills, which is common in autistic children, is generally a result of inadequate social skills and lack of creativity (Pişkin, 1993).

Social and behavioral inadequacies can be risk factors in children who have autistic spectrum disorder with low-level activity. Non-autistic children play with their peers, go to school or attend team sports, while autistic children may demonstrate difficulties in forming eye contact, showing interest in social games, communicating, making friends and attending physical activity. These features of autism prevent autistic children from attending successfully to physical activity programs and from being active physically (Yanardă̆, 2009).

There are few researches about sports for disabled individuals and most of the training programs for these individuals are based on the information gathered from the studies conducted with sportspeople without disabilities. Field researchers who understand the science of sport should conduct original researches with the use of tools designed and rules adapted for disabled people. In this context, this study fills an important gap in the field.

\section{Method}

\subsection{Research Model}

This is an action research based on qualitative research approach. The purpose of using action research with qualitative methods is the lack of flexible structure and generalization in qualitative research (Yildirım and Şimşek, 2013). This research is planned to be an action research based on a liberating / constructive / critical approach that aims to enable the participant individuals to improve education through playing games. When action researches are used in education, teacher can perceive his/her profession as a research process (Mills, 2000; qtd in Yıldırım and Şimşek, 2013).

\subsection{Participants}

This research is conducted with one pair of male twins who showed autistic features at the age of 6 . Easily accessible case sampling method of purposeful sampling methods is used in determination of participants to serve the purpose of qualitative research. Easy case sampling approach enables the researcher to act quickly and practically. The researcher has conducted this study with one pair of male twins who showed autistic features with the approval of the volunteer family.

\subsection{Gathering Data}

"Semi-structured interview" technique is used in this research. This interview technique consists carefully written and aligned questions, and each participant is asked these questions in the same style and sequence. In this respect, this approach reduces the differences that might come up due to skills, tendencies or subjectivities of several interviewees (Yıldırım and Şimşek, 2013).

\subsection{Action (Application) Plan}

Action researches focus on the process. The aim is to study the process within its own environment and to gather data on the focused problem. In this process understanding the problem, applying solution options and evaluating the results take place within the action research (Yıldırım and Şimşek; 2013).

This research has been conducted for 10 weeks. It took 2 hours a day and one day each week; in total it took 20 hours. Within this process, the application was conducted by 2 candidates of physical education teacher: one of them was a researcher and the other was an assistant.

Before the activity, the researcher prepared application plans and informed the teacher candidates and the family of participant individuals about the application. Before the application, a face-to-face interview was conducted 
with the family. All the details related to action (application) phase following the pre-activity phase are given in Table 1. After the action, the researcher evaluated the results of the application with a family interview.

Table 1. Action (Application) plan

\begin{tabular}{|c|c|c|}
\hline Week & Application Content & Application Details \\
\hline 1. Week & Color Games & $\begin{array}{l}\text { Assist. Prof. Dr. and Teacher Candidates } \\
\text { (1 male assistant }-1 \text { female assistant })\end{array}$ \\
\hline 2. Week & Concepts of Inside Outside Games & $\begin{array}{l}\text { Assist. Prof. Dr. and Teacher Candidates } \\
\text { ( } 2 \text { male assistant ) }\end{array}$ \\
\hline 3. Week & Concepts of Big Small Games & $\begin{array}{l}\text { Assist. Prof. Dr. and Teacher Candidates } \\
\text { ( } 2 \text { male assistant) }\end{array}$ \\
\hline 4. Week & Memory Games & $\begin{array}{l}\text { Assist. Prof. Dr. and Teacher Candidates } \\
\text { (1 male assistant }-1 \text { female assistant })\end{array}$ \\
\hline 5. Week & Coordination Games & $\begin{array}{l}\text { Assist. Prof. Dr. and Teacher Candidates } \\
\text { ( } 2 \text { female assistant) }\end{array}$ \\
\hline 6. Week & Motor Skills Games & $\begin{array}{l}\text { Assist. Prof. Dr. and Teacher Candidates } \\
\text { ( } 2 \text { female assistant) }\end{array}$ \\
\hline 7. Week & Part to Whole Games & $\begin{array}{l}\text { Assist. Prof. Dr. and Teacher Candidates } \\
\text { ( } 2 \text { male assistant) }\end{array}$ \\
\hline 8. Week & Concept of Number Games & $\begin{array}{l}\text { Assist. Prof. Dr. and Teacher Candidates } \\
\text { ( } 2 \text { male assistant) }\end{array}$ \\
\hline 9. Week & $\begin{array}{l}\text { Concept of Close, Distant and } \\
\text { Direction Games }\end{array}$ & $\begin{array}{l}\text { Assist. Prof. Dr. and Teacher Candidates } \\
\text { (1 male assistant }-1 \text { female assistant })\end{array}$ \\
\hline 10. Week & Balance Games and Horse Riding & $\begin{array}{l}\text { Assist. Prof. Dr. and Teacher Candidates } \\
\text { (1 male assistant }-1 \text { female assistant })\end{array}$ \\
\hline
\end{tabular}

\subsection{Data Analysis}

Descriptive analysis and content analysis are used in this research. Data gathered by the use of sound recording device in descriptive analysis is processed and transferred to electronic environment by the specialist researcher on qualitative analysis. Moreover, consistency between short notes taken by the researcher and findings are checked. In content analysis of data, first of all data gathered through face-to-face interview is transferred into prose in computer environment. Afterwards, this data is transferred into NVIVO 10 program. Following this phase, all of the procedures are done through NVIVO 10 program. NVIVO provides convenience for classification and coding data and sources systematically, accessing themes and presenting the results as a model.

The researcher and two specialists who are experienced on qualitative research do all of the procedures during the data analysis process; these researcher and specialists worked independently from each other. Consistent statements revealed during coding are grouped as themes.

\subsection{Validity and Credibility}

Lincoln and Guba (1985) suggest that using the concepts of cogency, transmissibility, consistency and confirmation would serve the purpose of providing validity and credibility in qualitative research. (qtd in Yildırım and Şimşek, 2013).

Credibility is based on several methods such as long-term interaction, data gathering focused on diversification and profundity, expert analysis and participant confirmation. The researcher in this study has been administering physical education and sports for disabled people class for ten years, attended several seminars related to disabled people, gave playing games education for disabled people classes to youth leaders within the body of Ministry of Youth and Sports and served as a member in the board of education in the Federation of the Visually Handicapped. These experiences has strengthened the researcher's long-term interaction with the field and enabled the researcher to understand the situations that are created by subjective perceptions on data sources. Moreover, field notes that 
are taken by the researcher during the process of action due to her position as participant observer throughout face-to-face interviews offer variety (Tobin and Begley, 2004; Briller, Meert, Schim and Thurston, 2008; Bekhet and Zauszniewski, 2012) and increase cogency of this study.

In order to strengthen transmissibility, which is adopted in lieu with generalization in qualitative research (Yıldırım and Şimşek, 2013), easily accessible case sampling method of purposeful sampling methods is used in this research.

The researcher and three field specialists have organized data and created themes for the consistency of this research. "Unanimity" and "difference of opinion" are two statements that are used for the codes and themes determined by the researcher and field specialists. Credibility formula of Miles and Huberman (1994) is used in this research for the calculation of credibility.

$$
\text { Reconciliation Percentage } \%=[\mathrm{Na} \text { (Unanimity) } / \mathrm{Na} \text { (Unanimity) }+\mathrm{Nd} \text { (Difference of Opinion) }] \mathrm{X} 100
$$

For all of the statements, unanimity is defined as 15 codes, and difference of opinion as 3 . According to the formula of Miles and Huberman (1994) the credibility of the research is calculated as $83 \%$. Reaching a result over $70 \%$ is a valid rate for the credibility of the research (Miles and Huberman; 1994).

The researcher will reserve all the data gathering tools, raw data and coding that are done during the analysis for re-analysis and for the confirmation (external credibility) of this research.

\section{Findings}

Behavioral approach towards the participants is determined by interviewing the mother before the application about the peculiarities of the participants. Based on the interview with the mother, peculiarities of the participants are thematized under four parts: favorites (home environment - shopping - soft ground - public transport vehicles - contact - playing with animals - playing games - cartoon characters), dislikes (loud music - too much sound singing - insincerity - chilliness - excessive unkind treatment), indifferent (to colors - to partisanship) and self-care skills (eating by oneself - going to toilet with assistance - getting dressed). These themes are shown on Figure 1.

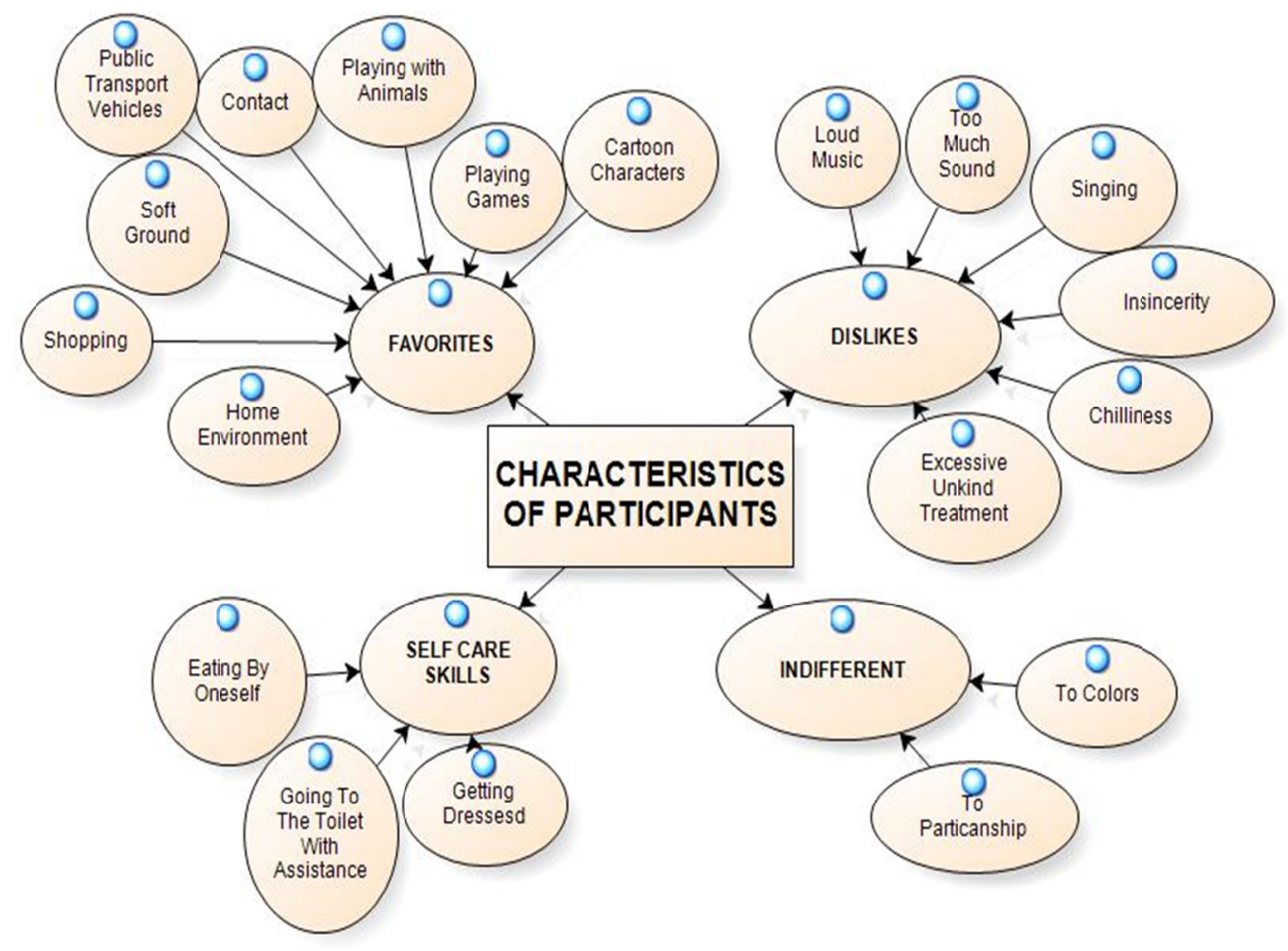

Figure 1. Peculiarities of the participants 

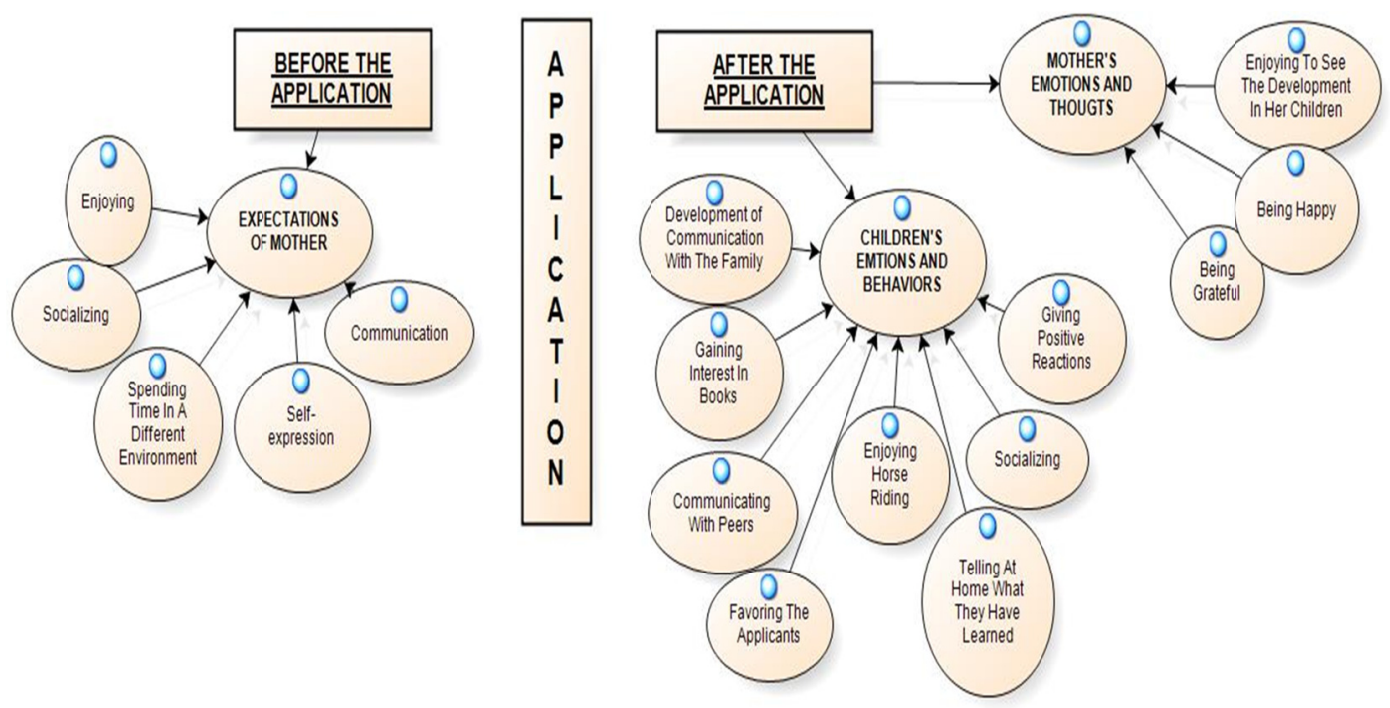

Figure 2. Application cycle

Expectations of the mother regarding her children before the application are stated as enjoying, socializing, spending time in a different environment, self-expression and communication. These statements are shown in Table 2.

Table 2. Expectations of the mother

\begin{tabular}{|c|c|}
\hline & Statements \\
\hline Enjoying & I want them to enjoy the applications. \\
\hline Socializing & $\begin{array}{l}\text { It would make me happy if I see them become more } \\
\text { extrovert and socialize. }\end{array}$ \\
\hline Spending time in a different environment & $\begin{array}{l}\text { I am impatient to see what they will do when they } \\
\text { spend time in different environments according to } \\
\text { your application program. }\end{array}$ \\
\hline Self-expression & I want them to express themselves. \\
\hline Communication & $\begin{array}{l}\text { My utmost expectation is to see them communicate } \\
\text { more. }\end{array}$ \\
\hline
\end{tabular}

The results of the application are grouped under mother's emotions and thoughts (enjoying to see the development in her children - being happy - being grateful) and children's emotions and behaviors (development of communication with the family - gaining interest in books - communicating with peers favoring the applications - enjoying horse riding - telling at home what they have learned - socializing - giving positive reactions). These statements are shown in Tables 3-4.

Table 3. Mother's emotions and thoughts

\begin{tabular}{ll}
\hline Statements \\
\hline Being happy & $\begin{array}{l}\text { It was priceless to see their development and listen } \\
\text { them every day narrating with joy what they had done. } \\
\text { It made us very happy to see their enthusiasm about } \\
\text { Bisiting you each Monday. }\end{array}$ \\
& $\begin{array}{l}\text { I am grateful to everyone who took part in this } \\
\text { project; it was so great to observe the improvement in } \\
\text { my children. }\end{array}$ \\
\hline
\end{tabular}


Table 4. Children's emotions and behaviors

\begin{tabular}{|c|c|}
\hline & Statements \\
\hline Development of communication with the family & $\begin{array}{l}\text { They began to communicate more with us. They told } \\
\text { more and expected us to listen. }\end{array}$ \\
\hline Gaining interest in books & $\begin{array}{l}\text { Following the activities, they began to have different } \\
\text { fields of interest. They began to try reading books. }\end{array}$ \\
\hline Communicating with peers & $\begin{array}{l}\text { They began to talk more with their peers at school and } \\
\text { in the neighborhood, even with the grocery store } \\
\text { owner in our neighborhood. }\end{array}$ \\
\hline Favoring the applications & $\begin{array}{l}\text { We began to hear such sentences as "I played tennis, } \\
\text { I painted, we went to see a soccer game" more } \\
\text { frequently. }\end{array}$ \\
\hline Enjoying horse riding & $\begin{array}{l}\text { Horse therapy did good, they began to care about } \\
\text { horses and they began to like horses very much. We } \\
\text { went horse riding twice after the applications. }\end{array}$ \\
\hline Telling at home what they have learned & $\begin{array}{l}\text { They began to tell us what they had done as soon as } \\
\text { they came home. }\end{array}$ \\
\hline Socializing & $\begin{array}{l}\text { Our primary expectation was socializing as we } \\
\text { mentioned in the first interview and it is getting better } \\
\text { in every environment they enter. }\end{array}$ \\
\hline Giving positive reactions & $\begin{array}{l}\text { They began to show endearment towards the } \\
\text { applications they participated and weekly application } \\
\text { teachers they met. }\end{array}$ \\
\hline
\end{tabular}

\section{Discussion and Conclusion}

The results obtained from this research are grouped under two categories: mother's emotions and thoughts (enjoying to see the development in her children - being happy - being grateful) and children's emotions and behaviors (development of communication with the family - gaining interest in books - communicating with peers - favoring the applications - enjoying horse riding - telling at home what they have learned - socializing giving positive reactions). The expectations of the family generally concentrate on the joy that their children will experience, their development in communication, their ability to give positive reactions and socializing. The results obtained from this research show that the desired improvements are achieved.

The influence of playing games and sport activities on individuals is certain. Frankel, F.D. Gorospe, C.M., Chang, Ya.C. \& Sugar, C.A. (2011) conduct a similar study on individuals with autism spectrum disorder. They analyze the reports kept by mothers and the behaviors of children while playing at school. They conclude that the games that the children play with their peers are important for demographic, social, general and cognitive variables.

In terms of enjoving aspect; Eversole, M. (2016) emphasizes that autistic individuals within 6-13 age group attend leisure time activities in order to have fun and that they enjoy it. No difference has been detected between age groups.

In terms of the view that playing activities affect socializing positively, which was supported by the results of this research; Roncaglia (2014) states in her study that sports and training eliminate stress and anxiety in autistic individuals and Kunzi (2015) states in his study conducted on individuals with autism spectrum disorder that troubles experienced in socializing can create depression, anxiety, aggression and physical health issues. The study, which proves that integrated sport and playing can eliminate such problems and Yu Pan's study (2010), which is based on a 10-week swimming training program applied on autistic children, proving that the children demonstrate skills and social development as a result of such programs are in parallel with the results of this study. The children told their experiences of horse riding exercise to their families and desired to continue after the conclusion of this study. The importance of horse riding exercise in autistic children is emphasized by Margaret M. Bass, Catherine A. Duchowny and Maria M. Llabre (2009) in their study conducted on autistic children. The influence of horse riding exercise on socializing for autistic children is revealed. The results also reveal that horse riding can be used for the treatment of autistic children. Hess L.'s study (2006) emphasizes that 
game activities contribute to the improvement of social skills due to autistic children's ability to imitate. It is observed that, due to their ability to imitate, they give answers quickly and easily to the questions they receive while playing. It is also observed that their social skills develop while fulfilling their roles during imitation games. Another study about the influence of physical activity on socializing is Awamleh and Woll's (2014) work, which asks whether physical activity helps a child with autism. As a result of this study, too, it is emphasized that physical activity plays an important role in eliminating social and communicative inadequacy, which can be considered as a characteristic feature of autistic individuals.

In terms of positive influence of playing; Holmes and Willoughby's study (2005), which is conducted on individuals with autism spectrum disorder, analyzes the individuals' behaviors during the games they play at school environment. This study also includes the opinions of mothers about the games. There are two studies which support the results obtained by this study: the first one proves that games have a positive influence on children based on the views of both mothers and trainers, and the second one is Misty L. Oppenheim-Leaf, Justin B. Leaf, Nikki A. Call's study (2012), which is conducted with two autistic children and it is observed that children improve their interaction skills with their peers through games. Karakaş and Yaman's (2014) study, conducted on disabled children, reveals positive effects of family contribution in attracting children with disabilities to exercise and emphasizes the benefits of sports to both families and children with disabilities.

In conclusion, beginning from the contributions of game activities on the development of disabled people, this research studies the influence of game activities on autistic individuals and aims to emphasize the importance of such activities for disabled individuals. The results show that disabled people at earlier age and education groups needs to be involved in such studies and activities in order to increase their effect on the improvement of disabled people. Further studies on the differences between disability groups that are excluded in this study, comparisons between genders, conducting similar researches on disabled individuals from different socio-economic backgrounds might reveal new approaches and guide other researchers.

\section{References}

Awamleh, A.A., \& Woll, A. (2014). The Influence Of Physical Exercise On Individuals With Autısm: Is Physical Exercise Able To Help Autistic?. Journal of Social Sciences, 10(2), 46-50. https://doi.org/10.3844/jssp.2014.46.50

Ayan, S., Memiş, U.A., Eynur, B.R., \& Kabakçı, A. (2012). Özel Eğitime İhtiyaç Duyan Çocuklarda Oyuncak Ve Oyunun Önemi. Uluslararası Hakemli Akademik Spor Sağllk Ve Tip Bilimleri Dergisi, 2(4), Jel Kodu: I-Q, 80-89.

Bekhet, A.K., \& Zauszniewski, J.A. (2012). Methodological triangulation: An approach to understanding data. Nurse Researcher, 20(2), 40-43. https://doi.org/10.7748/nr2012.11.20.2.40.c9442

Briller, S.H., Meert, K.L., Schim, S.M., \& Thurston, C.S. (2008). Implementing a triangulation protocol in bereavement research: a methodological discussion. Omega, 57(3), 245-260. https://doi.org/10.2190/om.57.3.b

Eversole, M., et al.. (2016). Leisure Activity Enjoyment of Children with Autism Spectrum Disorders. $J$ Autism Dev Disord, 46, 10-20. https://doi.org/10.1007/s10803-015-2529-z

Frankel, F.D., Gorospe, C.M., Chang, Ya.C., \& Sugar, C.A. (2011). Mothers' reports of play dates and observation of school playground behavior of children having high-functioning autism spectrum disorders. Journal of Child Psychology and Psychiatry, 52(5), 571-579.

Hess, L. (2006). I would like to play but I don't know how: a case study of pretend play in autism. Child Language Teaching and Therapy, 22(1), 97-116. https://doi.org/10.1191/0265659006ct299oa

Holmes, E., \& Willoughby, T. (2005, September). Play behaviour of children with autism spectrum disorders. Journal of Intellectual \& Developmental Disability, 30(3), 156-164. https://doi.org/10.1080/13668250500204034

İlhan, L. (2009). zihinsel engelli çocuğu olan anne-babaların çocuklarının özel eğitimleri sürecinde beden eğitimi ve spor etkinliklerine yaklaşımlarının değerlendirilmesi. Niğde üniversitesi beden eğitimi ve spor bilimleri dergisi, 3(1).

Karakaş, G., \& Yaman, Ç. (2014). The role of family in motivating the children with disabilities to do sport. Procedia - Social and Behavioral Sciences, (152), 426-429. https://doi.org/10.1016/j.sbspro.2014.09.225 
Kunzi, K. (2015). Improving Social Skills of Adults with Autism Spectrum Disorder Through Physical Activity, Sports, and Games: A Review of the Literature. Adultspan Journal October, 14(2), 100-114. https://doi.org/10.1002/adsp.12008

Margaret, M., Bass, Catherine A. Duchowny, \& Maria, M. Llabre. (2009). The Effect of Therapeutic Horseback Riding on Social Functioning in Children with Autism. J Autism Dev Disord, (39), 1261-1267. https://doi.org/10.1007/s10803-009-0734-3

Miles, M.B., \& Huberman, A.M. (1994). Qualitative Data Analysis (2nd ed.). Thousand Oaks, CA: Sage Publications.

Misty, L., Oppenheim-Leaf, Justin B. Leaf, \& Nikki A. Call. (2012). Teaching Board Games to Two Children with an Autism Spectrum Disorder. $J$ Dev Phys Disabil, (24), 347-358. https://doi.org/10.1007/s10882-012-9274-4

Odluyurt, S. (2013). Kaynaştırmaya Devam Eden Otistik Özellikler Gösteren Çocuklara Kurallı Oyun Öğretiminde Akranları Tarafindan Doğrudan Model Olma ve Videoyla Model Olma Öğretiminin Etkilerinin Karşılaştırılması. Educational Sciences: Theory \& Practice, 13(1), 523-540.

Pişkin, Ü. (1993). Otistik Çocuklarda Oyun. Özel Eğitim Dergisi, 1(3), 43 -46.

Roncaglia, I. (2014). Coping Styles: A Better Understanding of Stress and Anxiety in Individuals With Autism Spectrum Conditions Through Sport and Exercise Models. Psychological Thought, 7(2), 134-143. https://doi.org/10.5964/psyct.v7i2.115

Tobin, G. A., \& Begley, C.M. (2004). Methodological rigour within a qualitative framework. Journal of Advanced Nursing, 48(4), 388-396.

Yanardağ, M., Ergun, Nevin, \& Yılmaz, İlker. (2009). Otistik çocuklarda adapte edilmiş egzersiz eğitiminin fiziksel uygunluk düzeyine etkisi. Fizyoterapi Rehabilitasyon, 20(1), 25-31.

Yıldırım, A., \& Şimşek, H. (2008). Sosyal Bilimlerde Nitel Araştırma Yöntemleri (7. Baskı). Ankara: Seçkin Yayınevi.

Yu, Pan C. (2010). Effects of water exercise swimming program on aquatic skills and social behaviors in children with autism spectrum disorders, Sage publications and the national autistic society, 9-28.

\section{Copyrights}

Copyright for this article is retained by the author(s), with first publication rights granted to the journal.

This is an open-access article distributed under the terms and conditions of the Creative Commons Attribution license (http://creativecommons.org/licenses/by/4.0/). 